ANUARIO DE EsTUdios MEDIEVALES $48 / 2$, julio-diciembre de 2018 , pp. 695-721

ISSN 0066-5061

https://doi.org/10.3989/aem.2018.48.2.06

\title{
UMA EMBAIXADA PORTUGUESA DO FINAL DA IDADE MÉDIA: DE LISBOA A ROMA, 1443-1445
}

\section{A PORTUGUESE EMBASSY IN THE LATE MIDDLE AGES: FROM LISBON TO ROME, 1443-1445}

DIOGO FARIA

Universidade do Porto, CEPESE, IEM - FCSH/UNL http://orcid.org/0000-0002-4640-6394

Resumo: Este artigo analisa uma embaixada enviada pelo regente de Portugal a Roma entre 1443 e 1445. Os objetivos, os resultados, o perfil do embaixador, as viagens e as finanças são os aspetos privilegiados.

Palavras-chave: diplomacia; embaixadas; embaixadores; viagens; Portugal; Roma.

Abstract: This article analyses an embassy sent by the Portuguese regent to Rome between 1443 and 1445 . The objectives, the results, the ambassador's profile, the journey and the finances are the aspects that are examined.

Keywords: diplomacy; embassies; ambassadors; trips; Portugal; Rome.

\section{SUMÁRIO}

1. Introdução.- 2. A paisagem política.- 2.1. Uma inédita menoridade régia.2.2. Portugal e o Papado durante a regência do infante D. Pedro.- 3. Objetivos da embaixada.- 4. O embaixador.- 5. De Lisboa a Roma.- 6. Em Roma.- 7. De Roma a Portugal.- 8. Finanças da embaixada.- 9. Conclusão.- 10. Apêndice: despesas da embaixada.- 11. Bibliografia citada.

\section{INTRODUÇÃO ${ }^{1}$}

No dia 3 de junho de 1446, o infante D. Pedro, regente do reino de Portugal, assinou um documento que colocava um ponto final numa missão diplomática protagonizada por um clérigo nos anos anteriores. Esse documento era uma carta de quitação, a missão havia sido uma embaixada à Santa Sé$^{2}$,

\footnotetext{
${ }^{1}$ Abreviaturas utilizadas: b. = baioca; d. = ducado de câmara; dob. = dobra.

${ }^{2}$ O papa era Eugénio IV (1431-1447), cujo pontificado foi marcado pela realização do concílio de Basileia, pela reafirmação do poder papal sobre o conciliar e pelos esforços de reunificação das igrejas cristãs latina e oriental. Sobre esta figura e esta fase da história do papado, veja-se: Gill 1961; Uginet 1994; Black 1998; Ullman 2003, pp. 200-217.
}

Cómo citar este artículo: Faria, Diogo (2018), Uma embaixada portuguesa do final da Idade Média: de Lisboa a Roma, 1443-1445, "Anuario de Estudios Medievales" 48/2, pp. 695-721. https://doi.org/10.3989/aem.2018.48.2.06

Copyright: (c) 2018 CSIC. This is an open-access article distributed under the terms of the Creative Commons Attribution 4.0 International (CC BY 4.0) License. 
e esse clérigo, que se chamava João, mas que é conhecido na historiografia portuguesa como João Manuel, saíra de Portugal como provincial da Ordem do Carmo e regressara ao reino como bispo de Ceuta. É essa operação diplomática que constitui o objeto deste estudo.

A diplomacia medieval portuguesa encontra-se, em grande medida, por estudar. Apesar da relativa abundância de obras de síntese ${ }^{3}$ e de trabalhos sobre relações bilaterais entre Portugal e diversas entidades políticas ${ }^{4}$, são muito escassos os estudos que focam os aspetos sociais e práticos da diplomacia, cada vez mais valorizados pela historiografia europeia ${ }^{5}$. Em parte, isso pode ser explicado pela escassez de fontes reveladoras de detalhes sobre o processo diplomático, como instruções aos diplomatas ou livros de contas de embaixadas, tal como existem para os reinos ibéricos de Aragão e Navarra. O documento que serve de base a este texto ${ }^{6}$ acaba por constituir uma exceção ${ }^{7}$. Trata-se de uma carta de quitação ${ }^{8}$, que conhecemos através do seu registo num livro da Chancelaria régia ${ }^{9}$, en que são referidas as receitas e despesas de uma missão diplomática concretizada entre 1443 e 1445. Esse diploma, permitindo seguir o rasto do dinheiro recebido e gasto por esta embaixada, é um excelente testemunho da forma como funcionaria, na prática, a diplomacia portuguesa deste período. O desafio deste trabalho é apreender o máximo de aspetos que for possível a partir do seu conteúdo ${ }^{10}$.

${ }^{3}$ Dadas à estampa tanto por historiadores profissionais (Macedo 2006; Martínez 2010) como por diplomatas de carreira Fragoso 1997; Magalhães 2000.

${ }^{4}$ Veja-se o balanço bibliográfico de Branco, Farelo 2011, pp. 248-259.

${ }^{5}$ Sobre a renovação da história da diplomacia medieval europeia, veja-se Watkins 2008 e Péquignot 2011.

${ }^{6}$ Arquivo Nacional da Torre do Tombo, Chancelaria de D. Afonso V, livro 5, f. 45v. A carta está publicada em Azevedo 1915, pp. 322-324.

${ }^{7}$ Existem outras cartas de quitação com referências a missões diplomáticas, mas não conheço nenhuma que permita discernir tão detalhadamente os aspetos práticos e logísticos de uma embaixada.

8 "Documento comprovativo da entrega de dinheiro ou objetos -os mais variados- recebidos em nome de outrem, do pagamento de uma dívida ou salário, de restituição de haveres emprestados, etc. Desempenhava uma função idêntica à dos atuais recibos". Gonçalves 1971, p. 530. Neste caso, o rei D. Afonso V passa a carta a D. João Manuel, que tinha desempenhado uma missão diplomática em Roma, discriminando os valores recebidos e despendidos durante a embaixada, e dando o diplomata por quite e livre de qualquer encargo em relação à Coroa (pelo contrário, como se verá, ficaria ainda credor do monarca).

${ }^{9}$ Para o reinado que nos ocupa, preservam-se 38 livros de Chancelaria, tendo-se perdido os registos relativos a 13 dos 43 anos de governação. Marques 1988, pp. 190-191. As cartas de quitação são uma presença constante nestes tomos, mas relativamente escassa. Estudos sobre os registos da administração central entre o século XIV e o primeiro quartel do século XVI revelam que raramente estas cartas correspondiam a mais do que $2 \%$ da documentação total. Homem 1990, pp. 83-84; Freitas 1999, pp. 55-56; Faria 2013, pp. 37-38.

${ }^{10}$ Sendo esta carta a fonte primordial do estudo, valorizar-se-á a análise dos aspetos organizacionais, logísticos e financeiros da missão. Ainda que não se ignore os objetivos, os resulta- 
O texto que se segue divide-se em oito secções que podem ser agrupadas em três partes fundamentais. Na primeira (que inclui os pontos 2, 3 e 4), contextualiza-se a missão, dando conta do cenário político em que se desenvolveu e apresentando os seus objetivos e o perfil do embaixador. $\mathrm{Na}$ segunda (pontos 5, 6 e 7), analisa-se as diferentes etapas da embaixada, prestando particular atenção aos itinerários, aos meios de transporte e às tarefas executadas por D. João Manuel em Roma. Por fim, no ponto 8 são tratados os aspetos financeiros da missão.

\section{A PAISAGEM POLÍTICA}

\subsection{Uma inédita menoridade régia}

No período compreendido entre o início desta missão, em 1443, e a outorga da referida carta de quitação, em 1446, vivia-se em Portugal um raro período de menoridade régia ${ }^{11}$. Em 1438, o rei D. Duarte [r. 1433-1438] tinha morrido deixando como descendente um jovem príncipe, Afonso [r. 14381481], à data com apenas seis anos. Esta situação era inédita na monarquia portuguesa. Desde a sua fundação, na primeira metade do século XII, nunca a morte de um monarca havia deixado o trono nas mãos de uma criança. Colocava-se pela primeira vez a questão de saber quem governaria como regente. Esse problema, à partida, estava resolvido pelo testamento do soberano falecido: seria a rainha viúva, Leonor, irmã dos famosos infantes de Aragão, a conduzir o reino. Esta veio a revelar-se uma solução infeliz, contestada por setores importantes da aristocracia e pelas principais cidades do reino. A rainha acabaria por ser afastada e substituída por D. Pedro, duque de Coimbra, irmão de D. Duarte e do famoso infante D. Henrique, conhecido como o Navegador. D. Pedro governou o reino durante quase dez anos, entre 1439 e 1448. Não sem suscitar o desenvolvimento de importantes focos de oposição às suas políticas, que culminariam com a sua morte, em 1449, na batalha de Alfarrobeira, às mãos do rei Afonso $\mathrm{V}$, a quem devolvera o poder no ano anterior. Ao longo desta década, a expansão portuguesa prosseguia através da exploração da costa ocidental africana, patrocinada sobretudo pelo infante D. Henrique, e da colonização dos arquipélagos atlânticos da Madeira e dos Açores. Ceuta continuava a ser, desde 1415, a única possessão cristã no Norte de África.

dos e o significado político desta embaixada, não se pretende aprofundar esses tópicos, pelo que o contributo deste trabalho é assumidamente menos original nesses domínios.

${ }^{11}$ Uma síntese da evolução política portuguesa neste período encontra-se em Sousa 1997, pp. 420-423. 


\subsection{Portugal e o Papado durante a regência do infante D. Pedro}

As relações entre Portugal e o Papado durante a regência do infante D. Pedro ainda não foram objeto de estudos aprofundados. Contudo, o trabalho realizado pelo Visconde de Santarém no século XIX, sumariando a documentação pontifícia preservada na Torre do Tombo, associado a alguns dados presentes nas fontes narrativas, permite avançar com as que parecem ser as principais linhas de força dessa relação ${ }^{12}$.

A governação do duque de Coimbra surge na ressaca do Concílio de Basileia, que se cindiu em 1437, com as entidades políticas fiéis ao papa Eugénio IV a prosseguirem os trabalhos mais tarde em Florença e as restantes a suspenderem, deporem e substituírem este pontífice ${ }^{13}$. Portugal foi representado nesta reunião pelo bispo de Viseu, D. Luís do Amaral, enviado por D. João I no segundo semestre de 1433, ao qual se juntaram, entre outros, o conde de Ourém e o bispo do Porto, D. Antão Martins de Chaves, a partir de $1435^{14}$. O prelado viseense motivou uma discórdia entre D. Pedro e o papa logo em 1440: tendo assumido o partido dos cismáticos, ao contrário dos restantes membros da delegação portuguesa, foi excomungado e destituído por Eugénio IV, que nomeou D. Luís Coutinho para a prelazia da sua diocese. Num primeiro momento, o regente não aceitou este provimento, o que motivou a censura do $\operatorname{papa}^{15}$. A situação terá sido normalizada em $1441^{16}$, e é a normalidade que parece marcar o essencial dos contactos entre Portugal e o papado até 1448: durante cerca de uma década, foram negociados privilégios cruzadísticos, dispensas matrimoniais e diversos assuntos eclesiásticos (uma grande parte dos quais relacionadas com os territórios nacionais das dioceses de Tui e de Badajoz e com as Ordens Militares). As pretensões portuguesas, apresentadas em pelo menos três embaixadas ${ }^{17}$, parecem ter sido globalmente atendidas ${ }^{18}$.

\footnotetext{
${ }^{12}$ Que, naturalmente, só poderão ser confirmadas ou infirmadas por estudos muito mais aprofundados.

${ }^{13}$ Black 1998, pp. 70-74.

${ }^{14}$ A participação de Portugal no Concílio de Basileia foi estudada em Marques 2003-2004.

${ }^{15}$ Santarém 1866, vol. X, pp. 21-24.

${ }^{16}$ Baquero Moreno 1973, p. 789.

${ }^{17}$ A primeira, em 1440, protagonizada por Rui da Cunha, prior de Santa Maria de Guimarães, e por João Manuel. A segunda, possivelmente, entre 1441 e 1442, encabeçada por Fernão Lopes de Azevedo, comendador-mor da Ordem de Cristo. A terceira é a que é tratada neste trabalho: Pina 1977, pp. 673-674.

${ }^{18}$ Santarém 1866, vol. X, pp. 19-33.
} 


\section{OBJETIVOS DA EMBAIXADA}

A análise da documentação a que esta embaixada deu origem ${ }^{19}$ permite supor que terão sido pelo menos três os objetivos da missão de D. João Manuel:

- Incrementar os rendimentos da diocese de Ceuta através da alocação de rendas pertencentes a outros bispados.

- Alcançar a concessão dos mestrados das ordens militares de Santiago e de Avis, respetivamente, para o infante D. Fernando, filho de D. Duarte e irmão de Afonso V, e para D. Pedro, filho do regente com o mesmo nome do pai, que viria a ser efemeramente rei da Catalunha.

- Obter uma dispensa matrimonial para o casamento do infante D. Fernando com a prima D. Beatriz.

Pouco tempo após a conquista de Ceuta, em agosto de 1415, o rei D. João I [r. 1385-1433] solicitou ao papa a criação de uma diocese naquele território. O pontífice respondeu em abril de 1417, encarregando os arcebispos de Braga, D. Fernando da Guerra, e de Lisboa, D. Diogo Álvares de Brito, de avaliar o interesse e a validade das pretensões do monarca, concedendo-lhes a liberdade de elevarem o território de Ceuta à categoria de diocese caso isso lhes parecesse adequado. Assim aconteceu, através de uma sentença emitida por estes prelados em 6 de setembro de 1420, a que se seguiu o provimento do primeiro bispo em 5 de março de 1421. Sendo Ceuta um pequeno enclave cristão num Norte de África islâmico, eram escassos os rendimentos desta circunscrição eclesiástica. É possível que tenha sido ainda no tempo de D. João I que surgiu a ideia de anexar à jurisdição desta diocese territórios localizados em Portugal mas pertencentes aos bispados de Tui e de Badajoz ${ }^{20}$. Em 1436, o papa Eugénio IV rejeitou um primeiro pedido nesse sentido ${ }^{21}$. Esse assunto encontrava-se por resolver ainda no tempo da governação do infante D. Pedro ${ }^{22}$, e foi por isso uma das principais motivações desta embaixada.

\footnotetext{
${ }^{19}$ A carta de quitação e quatro bulas a que se fará menção mais à frente.

${ }^{20}$ Almeida 1967, p. 287.

${ }^{21}$ Braga, Braga 1998, pp. 144-145.

${ }^{22}$ A história da integração dos territórios do Entre Minho e Lima na diocese de Ceuta é sumariada em Marques 2015, pp. 21-22.
} 
Em relação às Ordens Militares, há que notar o progressivo interesse da monarquia em controlar os lugares cimeiros destas instituições. Tudo começou quando D. Pedro I [r. 1357-1367] obteve para um dos seus filhos ilegítimos, D. João, o mestrado da Ordem de Avis, em 1364. Já com este bastardo régio como monarca, assiste-se, numa primeira fase do reinado, ao provimento de homens muito próximos do rei como priores e mestres das ordens. Num segundo momento, serão os próprios filhos do soberano a ocupá-los: em 1418, o infante D. João é nomeado governador da Ordem de Santiago; em 1420, D. Henrique é feito administrador-geral da Ordem de Cristo; em 1434, já no reinado de D. Duarte, D. Fernando é provido como mestre de Avis ${ }^{23}$. Quando o infante D. Pedro incumbe D. João Manuel de obter junto do papa os mestrados de Santiago e Avis para D. Fernando e D. Pedro ${ }^{24}$, já se trata da segunda geração de membros da família real a ocuparem sistematicamente estes cargos. Desta vez, contudo, há uma nuance, já assinalada por Luís Adão da Fonseca: mantendo-se, nos dois casos, a linha de "absorção" do governo destas instituições pelo poder central, a nomeação de D. Pedro enquadra-se numa estratégia do pai que, tendo em conta a situação política interna convulsa já referida, procura assegurar a fidelidade dos titulares de alguns dos principais cargos do reino ${ }^{25}$.

Finalmente, a ideia do casamento do infante D. Fernando terá sido precipitada pelas mortes do infante D. João, em 1442, e do seu único varão, D. Diogo, em 1443. Sendo D. Fernando um filho segundo e detendo D. João importantes cargos e um vasto património, herdado pelas filhas, os infantes D. Pedro e D. Henrique terão visto como uma boa oportunidade um consórcio entre estes dois ramos da família. Assim, acordaram a união de D. Fernando com D. Beatriz, filha segunda do infante D. João ${ }^{26} \mathrm{e}$, por isso, sua prima coirmã ${ }^{27}$. Como é evidente, a concretização de um matrimónio entre primos direitos exigia uma dispensa pontifícia.

Em suma, esta missão é testemunho de três aspetos muito relevantes da política portuguesa do século XV (e, em particular, do seu processo de centralização) que, ao longo de várias décadas, foram objeto de negociações com o papado: a extensão e consolidação da malha eclesiástica portuguesa no Norte de África -também de especial significado para a Santa Sé, pela opor-

\footnotetext{
${ }^{23}$ Coelho 2008, pp. 288-289.

${ }^{24} \mathrm{O}$ mestrado de Santiago estava vago na sequência das mortes do infante D. João, em 1442, e do seu filho D. Diogo, em 1443. A liderança de Avis encontrava-se desocupada desde a morte do infante D. Fernando no seu cativeiro de Fez, em 1443.

${ }^{25}$ Fonseca 1982, p. 104.

${ }^{26}$ A sua irmã mais velha, D. Isabel, casaria em 1447 com Juan II de Castela, não podendo por isso manter o património que herdara em Portugal, que assim passava para as mãos da irmã.

${ }^{27}$ Costa 2007, pp. 44-45.
} 
tunidade de missionação que lhe poderia estar associada- em articulação com a 'nacionalização' de todo o território diocesano do reino; o aprofundamento do processo de absorção do governo das Ordens Militares pela monarquia; e a política de casamentos entre diversos ramos da família real, que assegurava que a maior parte dos grandes senhorios nobres se mantinha na órbita da coroa.

\section{O EMBAIXADOR}

Não sabemos ao certo quando nasceu nem de quem era filho D. João Manuel. Sabemos, contudo, de quem não era filho: do rei D. Duarte. Pode soar estranho iniciar um perfil biográfico indicando quem não era o pai do biografado, mas a verdade é que a ideia da ascendência régia deste clérigo encontra-se plasmada em muita historiografia. Ao que parece, tudo começou na segunda metade do século XVI, quando Gaspar Barreiros, numa carta a Damião de Góis, escreveu:

O dito Bispo da Guarda foy capellão moor del Rey D. Affonso o $5^{\circ}$ havido do dito Rey e do Infante D. Fernando seu yrmão por filho del Rey Dõ Duarte seu pay, e por tal foy dado a criar e pella mesma causa feito Religiozo do Carmo, o qual filho ouve o dito rey em huma Sr. ${ }^{a}$ castelhana que veyo a este reyno da linhagem dos Manueis de Castella ${ }^{28}$.

Muitos autores acabaram por dar como certa esta filiação, entre os quais avulta António Caetano de Sousa. Foi provavelmente a sua clássica História Genealógica da Casa Real Portuguesa ${ }^{29}$ que mais induziu em erro, ainda nas últimas décadas, vários historiadores ${ }^{30}$, apesar de Anselmo Braamcamp Freire, no início do século XX, ter demonstrado a impossibilidade de João Manuel ter sido filho de D. Duarte. Entre os diversos argumentos aduzidos, destaca-se a citação de um documento de 1488, em que um filho homónimo deste prelado refere que o pai, juntamente com o seu pai e a sua mãe, se encontrava sepultado no lado de fora de uma capela do convento do Carmo, em Lisboa ${ }^{31}$. Os mais recentes biógrafos de D. Duarte são unânimes na validação da argumentação de Braamcamp Freire ${ }^{32}$.

\footnotetext{
${ }^{28}$ Gaspar Barreiros, citado em Freire 1996, p. 13.

${ }^{29}$ Sousa 1946, p. 279.

${ }^{30}$ Por exemplo, Marques 1987, p. 231; Braga, Braga 1998, p. 143; Serrão 2003, p. 356.

${ }^{31}$ Freire 1996, pp. 10-16.

${ }^{32}$ Duarte 2007, pp. 354-356; Ventura 2013, p. 84.
} 
O que se sabe, então, sobre D. João Manuel? Esta figura deu origem a vários perfis biográficos ${ }^{33}$. Segundo eles, terá nascido no início do século $\mathrm{XV}$. Ingressou novo na vida religiosa, professando no convento do Carmo, em Lisboa, ainda em vida de D. Nuno Álvares Pereira, de quem foi muito próximo. Mais tarde, tornar-se-ia vigário geral, prior e provincial dos Carmelitas ${ }^{34}$, cargos que exerceria até ao fim da vida. Em 1437, participou na tentativa falhada de conquistar Tânger ${ }^{35}$. Durante a regência do infante D. Pedro, por três vezes desempenhou tarefas diplomáticas: encabeçou duas embaixadas a Roma, primeiro em 1440, ocasião em que foi nomeado bispo titular de Tiberíades ${ }^{36}$, e depois em 1443-1445; ter-se-á também deslocado à Hungria, por motivos que não foi possível apurar, em datas desconhecidas. Durante a segunda estadia em Roma, em 1444, foi nomeado bispo de Ceuta. Na conjuntura que culminou com a batalha de Alfarrobeira, atuou como emissário do infante D. Henrique junto de D. Pedro. É possível que tenha participado no enfrentamento militar de 1449, ao lado de D. Afonso V. No ano seguinte, foi beneficiado com doações de bens confiscados aos partidários de D. Pedro. Foi capelão-mor do Africano, pelo menos a partir de 1450. Em 1459, foi nomeado bispo da Guarda, cargo que ainda ocupava em 1476, quando morreu. Apesar disso, vivia na corte a maior parte do tempo. Presume-se que tenha sido autor de várias obras, hoje dadas como perdidas. Teve dois filhos de Justa Rodrigues, que seria ama-de-leite do futuro rei D. Manuel. A esse propósito, reza a lenda que João Manuel costumava dizer: Justa fue mi perdicion ${ }^{37}$.

Quando, em 1443, D. Pedro incumbe D. João Manuel de encabeçar a embaixada que é objeto deste estudo, o regente escolhe um homem que teria entre trinta e quarenta anos, que era um clérigo com alguma relevância ${ }^{38}$-os eclesiásticos continuavam a ser o grupo privilegiado de recrutamento de diplomatas enviados à Santa $\mathrm{Sé}^{39}$-, que fora próximo da monarquia desde muito

${ }^{33}$ Sá 1724,pp. 213-214; Paiva Manso 1872,pp. 32-34; Baquero Moreno 1973, pp. 850-852; Freire 1996, pp. 10-25.

${ }^{34}$ A Ordem do Carmo estabeleceu-se em Portugal na segunda metade do século XIII, quando foi fundado um convento localizado em Moura. No final do século XIV, Nuno Álvares Pereira promoveu a construção de uma nova casa religiosa carmelita em Lisboa. A Ordem autonomizou-se em relação a Castela em 1423, quando foi fundada a província portuguesa. Costa 1971, p. 490.

${ }^{35}$ A sua atuação nesta empresa militar mereceu os maiores elogios do cronista Rui de Pina. Pina 1977, p. 556.

${ }^{36}$ Um título meramente honorífico, relativo a um território atualmente localizado em Israel.

${ }^{37}$ Freire 1996, p. 10.

${ }^{38}$ Provincial de uma ordem religiosa que, ainda que pequena, era próxima da monarquia.

${ }^{39}$ Como já se referiu, as três embaixadas enviadas pelo regente D. Pedro à Santa Sé foram protagonizadas por clérigos. Esta tendência é confirmada pelos estudos de Isabel Beceiro Pita sobre o perfil dos embaixadores peninsulares no final da Idade Média: Beceiro Pita 1997, pp. 1739-1741; Beceiro Pita 2009, pp. 196-199. Catherine Fletcher demonstrou que a nomea- 
cedo $^{40}$ e que já tinha experiência diplomática ao mais alto nível. A missão que tinha desempenhado anos antes em Roma, juntamente com o prior de Guimarães, havia sido um sucesso, culminando com a obtenção da dispensa pontifícia para o casamento entre o rei D. Afonso V e a sua prima D. Isabel ${ }^{41}$. Podemos imaginar que o regente reconhecesse neste homem as principais qualidades que, segundo a literatura política da época, um embaixador deveria revelar: fidelidade, honestidade, sensatez, prudência e eloquência ${ }^{42}$. Para João Manuel, esta era uma nova oportunidade para, servindo a coroa a numa missão importante, se promover junto da cúria e, desse modo, impulsionar a sua carreira clerical ${ }^{43}$.

\section{DE LISBOA A ROMA}

Comecemos a seguir os passos desta embaixada ${ }^{44}$. Sabemos muito pouco sobre o que se passou antes da partida de Lisboa. Em 16 de julho de 1443, o infante D. Pedro subscreveu em Sintra um alvará ${ }^{45}$ através do qual, na prática, constituía a comitiva de D. João Manuel: cedia-lhe três servidores, cujas tarefas não são descritas, mas que eventualmente abrangeriam domínios como a assistência em tarefas burocráticas e a segurança pessoal. É provável, então, que tenha sido pelo princípio do verão que foi tomada a decisão, possivelmente numa reunião do conselho régio, de enviar esta missão a Roma, e que a mesma começou a ser preparada. $\mathrm{O}$ seu arranque aconteceria apenas alguns meses mais tarde ${ }^{46}$.

ção de eclesiásticos para missões junto da Santa Sé era uma "regra" só furada pelas potências italianas: Fletcher 2015, pp. 83-87.

${ }^{40}$ Veja-se a sua ligação ao condestável D. Nuno Álvares Pereira e ao seu neto, o conde de Ourém, assim como a sua participação no episódio de Tânger.

${ }^{41}$ Pina 1977, pp. 673-674.

${ }^{42}$ Péquignot 2012, p. 547.

${ }^{43}$ Analisando as relações entre a Inglaterra e o papado de Avinhão, Karsten Plöger notou que os benefícios que um clérigo poderia obter no decurso de uma missão diplomática junto do papa poderiam ser mais interessantes do que o pagamento pecuniário que adviria desse trabalho. Plöger 2005, pp. 165-166.

${ }^{44}$ Todos os dados avançados são baseados na carta de quitação passada a D. João Manuel, a não ser quando se faz menção expressa a outra documentação. Não se conhecem para a Idade Média portuguesa registos diários de contas de embaixadas como existem para outros reinos. $\mathrm{O}$ mais próximo disso, salvaguardadas as devidas distâncias (porque é um documento muito mais tardio e porque não se tratou de uma missão ao serviço da coroa), talvez seja a lista das despesas de uma viagem três clérigos enviados pelo mosteiro de Santa Cruz de Coimbra a Roma em 1588, estudada por Coelho, Santos 1990.

${ }^{45}$ Tanto quanto foi possível apurar, não se conhece nem o original deste documento, nem o seu registo nos livros da Chancelaria.

${ }^{46}$ Esta diferença de alguns meses entre o arranque da preparação de uma embaixada e a sua partida efetiva seria frequente no século XV. A faustosa embaixada encabeçada pelo conde de 
O itinerário que levou os representantes portugueses à cúria romana não é o mais evidente. A primeira etapa foi uma ligação entre Lisboa e Bruges, numa carraca fretada. Não é possível calcular quanto tempo demorou esta viagem, uma vez que se desconhece a data exata da partida. Sabe-se que João Manuel e os seus acompanhantes chegaram à Flandres no dia 8 de dezembro. Segundo Frederigo Melis, uma viagem entre Lisboa e Bruges, na Idade Média, demorava em média nove dias ${ }^{47}$, mas as condições atmosféricas e as características da embarcação podiam fazer variar significativamente este va$\operatorname{lor}^{48}$. Podemos apontar como provável, contudo, que a partida da embaixada tenha ocorrido nas últimas semanas de novembro.

E por quê viajar para Roma a partir de Bruges? Dois motivos ajudam a compreender esta opção. Por um lado, em meados do século XV os contactos comerciais entre Portugal e a Flandres eram muito intensos, pelo que com bastante regularidade partiam navios de Lisboa e de outros portos do reino em direção a Bruges ${ }^{49}$. Por outro, era nessa cidade flamenga que D. João Manuel iria aceder à primeira parte do financiamento da sua missão. Por esta altura, não era raro que os embaixadores portugueses viajassem munidos de letras de câmbio, que lhes permitiriam obter liquidez no estrangeiro para fazer face às suas despesas ${ }^{50}$. Neste caso, o provincial do Carmo transportava uma carta no valor de 320 ducados, passada por Tropell, um mercador genovês a residir em Lisboa, que deveria ser descontada em Bruges. Em certa medida, a chegada a essa cidade representava o início da missão propriamente dita de D. João Manuel, uma vez que só a partir desse dia começaria a receber o seu mantimento diário. Não há qualquer indício de que esta escala tenha sido aproveitada para efetuar contactos diplomáticos com a corte da Borgonha ${ }^{51}$, mas esta hipótese não pode ser completamente descartada.

A carta de quitação não se refere concretamente ao trajeto entre Bruges e a Península Itálica, ao que tudo indica efetuado por via terrestre, o que explica a compra de quatro bestas ${ }^{52}$. Apesar do declínio das feiras de Cham-

Ourém ao Concílio de Basileia foi constituída em 12 de setembro de 1435, tendo partido de Lisboa apenas no dia 11 de janeiro do ano seguinte. Dias 2003, pp. 9, 7.

${ }^{47}$ Molina 2000, p. 117.

${ }^{48}$ Foi o que aconteceu quando a infanta D. Isabel, filha de D. João I e de Filipa de Lencastre, se deslocou para a Flandres, onde casaria com o duque da Borgonha. Tendo partido de Lisboa a 8 de outubro, a comitiva apenas chegou a L'Écluse em 6 de dezembro, após paragens mais ou menos prolongadas em Cascais, Vigo, Ribadeo e Plymouth. Santarém 1843, vol. III, pp. 55-57.

${ }^{49}$ Miranda 2012, pp. 135-146.

${ }^{50}$ Marques 1987, pp. 74-75.

${ }^{51}$ Paviot 1995, p. 39.

${ }^{52}$ Não seria de excluir a hipótese de esta ligação ser efetuada por via marítima, visto que, desde 1297, eram diretas e regulares as viagens entre Bruges e o Mediterrâneo - Braudel 1992, p. 368. No entanto, parece-me altamente improvável que isso tenha acontecido. Para além de 
pagne, da Guerra dos Cem Anos, e da cada vez maior preponderância dos transportes marítimos, continuavam a existir ligações fortes, pelo centro do continente, entre o Norte da Europa e a Itália ${ }^{53}$, percorridas por diplomatas, clérigos, estudantes, peregrinos, etc ${ }^{54}$. É verosímil que essa viagem tenha durado pouco mais de um mês ${ }^{55}$.

Antes de chegar a Roma, João Manuel passou por Florença. Aí obteve a segunda parte do financiamento da missão: 250 ducados. No reinado de D. João I, a coroa portuguesa depositara uma soma de dinheiro muito elevada nessa cidade, ficando o abade D. Gomes de Florença como zelador desse capital $^{56}$. A documentação não indica qual era o objetivo de tal depósito, mas Luís Miguel Duarte levanta a hipótese de se tratar de um investimento (...) na política externa, destinado a constituir um fundo de maneio para quem houvesse de defender os interesses de Portugal, fossem os infantes em viagens, diplomatas ou o abade D. Gomes ${ }^{57}$. Em 1444, não terá sido fácil para D. João Manuel aceder a esse depósito. A carta de quitação refere mesmo uma demanda que ouve com os monges de Frollença sobre as pagas dos dinheiros que a nos avijam de fazer. Fosse como fosse, o resultado da contenda foi positivo e permitiu ao embaixador chegar a Roma com os bolsos mais pesados.

Uma vez mais, a carta de quitação é omissa em relação à data da chegada da embaixada à corte papal. Mas sabemos que isso aconteceu,

a compra de quatro bestas indiciar uma viagem terrestre, a carta de quitação que tenho seguido indica os custos de três viagens marítimas: de Lisboa a Bruges, de Sagona a Cádis e de Cádis a Castro Marim. A ter acontecido uma ligação desse tipo entre Bruges e a Península Itálica (que seria a mais longa e, eventualmente, a mais cara de toda a missão), dificilmente não seria elencada no rol das despesas do embaixador.

${ }^{53}$ A rede de estradas da França medieval era extremamente desenvolvida e até comparável à atual, Bautier, citado por Plöger 2005, p. 153. Eva Pibiri estudou itinerários seguidos por embaixadores da Saboia em direção à Flandres (tanto atravessando a Alemanha como passando pela França), que poderão não ser muito diferentes do que foi percorrido por D. João Manuel. Pibiri 2011, pp. 356-359, 367-369.

${ }^{54}$ As peregrinações medievais a Roma e os itinerários seguidos pelos peregrinos foram estudados por Birch 2000.

${ }^{55}$ Calcula-se que os viajantes do final da Idade Média, a cavalo, pudessem percorrer cerca de 60 a $70 \mathrm{~km}$ por dia -Plöger 2005, p. 155-, mas vários fatores condicionavam a sua marcha e este valor indicativo tem de ser olhado com muita prudência. No caso das viagens para a Península Itálica, os Alpes constituíam um obstáculo considerável, que poderia ser muitíssimo complicado de ultrapassar em função das condições meteorológicas. Para além disso, como já demonstraram estudos que se debruçaram sobre itinerários detalhados, a distância percorrida em cada etapa das viagens podia variar muitíssimo -Gonçalves 1980, pp. 126-127; Pibiri 2011, pp. 430-450. Eva Pibiri notou que, normalmente, após dias em que as deslocações se prolongavam desde a manhã até ao fim da tarde, seria frequente que a marcha só fosse retomada no dia seguinte depois do almoço. Segundo Anne-Brigitte Spitzbarth, uma viagem de Lille a Roma no século XV durava em média 40 dias. Spitzbarth 2013,p. 434.

${ }^{56}$ A ação de D. Gomes enquanto abade de Florença foi estuda por Nunes 1964.

${ }^{57}$ Duarte 2007, pp. 196-197. 
seguramente, antes de 29 de $\operatorname{março~}^{58}$, pois é a partir dessa data que o sumo pontífice começa a emitir documentos que resultam diretamente desta missão.

\section{EM ROMA}

O documento que tem sido estudado não permite avançar muitos dados sobre a longa estadia, de quase um ano ${ }^{59}$, de D. João Manuel em Roma. Não sabemos onde ficou hospedado, quantos encontros teve com o papa e os seus oficiais, que avanços e recuos existiram nas negociações. Apesar disso, é possível reconstituir, pelo menos em parte, o ambiente em que se moveu, aquilo que conseguiu obter do pontífice e, até certo ponto, a forma como alcançou os seus objetivos.

A eleição de Martinho V, em 1417, e o consequente fim do Cisma do Ocidente fizeram de Roma, de novo, o coração da Cristandade. Graças à importância jurídica e religiosa do papado e à permanentemente instável situação política da Península Itálica ao longo do século XV, a cidade que D. João Manuel viria a encontrar tornou-se um cada vez mais fervilhante espaço de convivência de diplomatas de diversas proveniências e de concentração e difusão de notícias e de rumores ${ }^{60}$. Lapo de Castiglionchio, um humanista que foi oficial da cúria, descreveu este ambiente em 1438, dando conta da beleza e da elegância do movimento de embaixadores dos mais diversos reis da Europa que a todo o momento entravam e saíam de Roma ${ }^{61}$.

D. João Manuel terá lá chegado em princípios de 1444. Tendo em conta o que era habitual na diplomacia deste tempo ${ }^{62}$, é provável que, uma vez instalado na cidade, tenha tido um primeiro contacto com o papa numa receção solene. Nesse encontro, de que não restam testemunhos ${ }^{63}$, terá apresen-

\footnotetext{
${ }^{58}$ Provavelmente, algumas semanas antes dessa data.

${ }^{59}$ Excedendo, portanto, os seis meses que os diplomatas estavam autorizados a permanecer na cidade, segundo uma não muito respeitada provisão de Martinho V. Fletcher 2015, pp. 17-18.

${ }^{60}$ Segundo Garrett Mattingly, durante o Renascimento, Roma foi "the nerve center of diplomacy and its chief gossip shop" -Mattingly 1988, p. 137-, mas já antes do Cisma a cúria seria um meio privilegiado de obtenção de informação -Péquignot 2009,pp. 106-108. A importância de Roma como coração da diplomacia europeia desta época é analisada em Shaw 2007 e em Fletcher 2015, pp. 15-35.

${ }^{61}$ Fletcher 2015, p. 18.

${ }^{62}$ Hamilton, Langhorne 1995, pp. 47-52; Mattingly 1988, pp. 30-38; Ochoa Brun 1995, pp. 394-412; Péquignot 2012, pp. 544-552.

${ }^{63}$ Eva Pibiri, analisando a diplomacia do ducado da Saboia, sobre a qual se preservam registos financeiros muito detalhados, nota que esta primeira audiência, por normalmente não implicar a qualquer despesa, é muito pouco mencionada na documentação. Pibiri 2011, p. 153. A esse nível, o caso português não é diferente.
} 
tado as suas credenciais ${ }^{64}$, anunciado os objetivos da sua missão e exibido perante Eugénio IV o seu domínio do latim, algo muito apreciado na corte pontifícia.

Uma vez que esta era uma embaixada com objetivos negociais e não propriamente cerimoniais, o verdadeiro trabalho só começaria após a primeira audiência com o papa. Ao longo de muitas semanas, D. João Manuel terá mantido várias reuniões com oficiais da cúria romana e com outros diplomatas ${ }^{65}$. O resultado desses contactos foi o cumprimento dos objetivos da sua missão ${ }^{66}$ :

- No dia 29 de março, Eugénio IV emitiu uma bula em que concedia a D. Pedro, filho do regente D. Pedro, o mestrado da Ordem de Avis ${ }^{67}$.

- A 23 de maio, o papa nomeou o infante D. Fernando mestre da Ordem de Santiago ${ }^{68}$.

- Em 14 de julho, o pontífice determinou a incorporação nos bens da diocese de Ceuta dos territórios detidos pelos bispados de Tui (Valença do Minho) e de Badajoz (Olivença) em Portugal ${ }^{69}$.

- Em data que não foi possível apurar, também a dispensa para o casamento do infante D. Fernando foi obtida ${ }^{70}$, apesar dos esforços de diplomatas aragoneses junto do papa para que isso não acontecesse ${ }^{71}$.

${ }^{64}$ Não há vestígios dos documentos de que D. João Manuel dispôs e se serviu durante esta embaixada, mas terão sido vários e de diversas espécies: uma carta de crença para apresentar ao papa; instruções com detalhes sobre os assuntos a tratar; salvo-condutos que lhe garantiam segurança nas diferentes entidades políticas que atravessou (e que podiam ser obtidos antes ou durante a embaixada); letras de câmbio; procurações para apresentar no banco de Florença; eventualmente, correspondência dirigida a membros da cúria e diplomas que fundamentassem as petições que apresentaria a Eugénio IV.

${ }^{65}$ Estudos recentes sobre as negociações diplomáticas na Idade Média demonstram como por vezes os processos negociais eram lentos e complexos, sendo condicionados por uma multiplicidade de fatores que podiam ir desde a delicadeza da matéria a tratar até à (boa ou má) disposição do senhor com quem se negoceia. Dão conta dessas vicissitudes trabalhos como os de Lazzarini 2010 e Péquignot 2010 (ainda que este não trate de relações com o papado).

${ }^{66} \mathrm{Ou}$ de parte deles, visto que, na verdade, não temos conhecimento de eventuais súplicas que, por terem sido indeferidas, não deixaram rasto documental.

${ }^{67}$ Dinis 1967, pp. 153-155.

${ }^{68}$ Ibidem, pp. 165-169.

${ }^{69}$ Ibidem, pp. 196-201. Esta decisão seria anulada por Nicolau V em 1452, mas voltaria a ser confirmada por Calisto III em 1456 e por Pio II em 1463. Braga, Braga 1998, p. 145.

${ }^{70}$ Azevedo 1915, p. 323.

${ }^{71}$ Dinis 1967 , pp. 150-151. 
A carta de quitação relativa a esta missão dá conta de várias despesas que foram feitas para alcançar estes desígnios. Esses gastos permitem-nos ter alguma ideia de como seria o dia-a-dia das negociações em Roma. Por um lado, parte do tempo e do dinheiro seria investido no cumprimento de trâmites burocráticos, que passariam pela redação de documentos -as súplicas- pela solicitação das bulas e pelo pagamento de taxas. Tendo em conta a reduzida dimensão da sua comitiva, D. João Manuel sentiu a necessidade de recorrer aos serviços de um secretário do duque da Borgonha, porventura mais conhecedor dos meandros da diplomacia pontifícia, a quem pagou para que lhe escrevesse algumas cartas. Por outro lado, a rotina dos embaixadores passaria pelo exercício daquilo a que hoje chamamos lobbying, e que deve ser entendido como um conjunto de atividades de negociação e de pressão, não ilegítima ou ilegal. Provavelmente é aí que encaixam os 100 ducados de câmara pagos a "Mourenensy" para "com boa deligencia" solicitar o que o embaixador pretendia, assim como os 20 ducados que recebeu um taxador para que uma taxa de 4.000 ducados se convertesse nuns módicos $40 \ldots$

Desta estadia em Roma resultou ainda algo que talvez D. João Manuel estivesse longe de prever quando partiu de Lisboa nos meses finais de 1443. Entre 21 de janeiro e 1 de julho de 1444, morreu D. Fr. Aimaro de Aurillac, um franciscano inglês que integrara a casa da rainha Filipa de Lencastre e que em 1421 se tornou no primeiro bispo de Ceuta. O período de sede vacante foi curto, e em 20 de julho o papa Eugénio IV nomeou João Manuel como prelado da diocese do Norte de África ${ }^{72}$. Estando no local certo na hora certa, será difícil determinar se este provimento do diplomata português se deveu à boa impressão que terá causado junto do pontífice ou à sua capacidade de negociação, pressão e circulação pelos corredores da política do Vaticano (ou às duas coisas, claro...).

\section{De Roma A Portugal}

Sobre o regresso de D. João Manuel e da sua comitiva a Portugal, sabemos que foi efetuado por via marítima e que incluiu pelo menos três viagens. No dia 8 de dezembro de 1444, o embaixador partiu de Roma. Cerca de um mês e meio depois, em 22 de janeiro de 1445, embarcou em Sagona, na Córsega, numa carraca que o levou até Cádis. Note-se que não fez escala em Ceuta, terra de que era bispo. Seguiu-se uma ligação numa barca até Castro Marim. O diplomata entrou em Portugal no dia 20 de maio, quase meio ano

${ }^{72}$ Ibidem, pp. 205-211. 
depois de ter partido de Roma. Esta viagem foi extraordinariamente longa. A carta de quitação refere mesmo que a ligação entre Sagona e Cádis, que em condições normais se realizaria em alguns dias, durou quatro meses e meio. A documentação não avança qualquer explicação para esta demora, e mesmo o facto de a navegação no Mediterrâneo abrandar o ritmo nos meses de novembro, dezembro e janeiro, devido ao clima ${ }^{73}$, não parece suficiente para justificar tanto tempo supostamente passado no mar. É possível que durante este período João Manuel tenha desempenhado alguma missão no Mediterrâneo Ocidental, eventualmente em Barcelona, em Valência ou mesmo em Ceuta, que não interessou registar. A não ser que existam documentos que eu não conheço sobre este assunto, o mais provável é que nunca venhamos a saber o que realmente se passou.

\section{FINANÇAS DA EMBAIXADA}

A última parte deste texto é dedicada às finanças da embaixada. Suportar financeiramente a diplomacia era um desafio para as monarquias medievais: os custos eram irregulares, muitas vezes elevados, quase sempre sujeitos a variações imprevistas ${ }^{74}$. Com base nos elementos disponíveis na carta de quitação, serão analisadas as receitas e as despesas da missão. Idealmente, esses dados deveriam ser confrontados com os balanços financeiros de outras embaixadas, mas esse exercício é muito condicionado pela singularidade do documento que serve de base a este estudo.

Há, contudo, uma comparação que é possível efetuar, ainda que com algumas reservas ${ }^{75}$. Segundo uma lista de despesas da coroa portuguesa com embaixadas entre 1415 e 1473, a que foi encabeçada por D. João Manuel custou no total 320 dobras. Tendo em conta um conjunto de 77 missões, verifica-se que, em média ${ }^{76}$, cada uma destas operações diplomáticas custou cerca

${ }^{73}$ Molina 2000,p. 114.

${ }^{74}$ Péquignot 2009, p. 152.

${ }^{75}$ A principal reserva prende-se com o facto de a maioria dos dados da carta de quitação estar expressa em ducados de câmara, enquanto os valores do documento que permite efetuar esta comparação se encontram em dobras. Não tendo tido oportunidade de verificar a equivalência entre estas duas moedas, não pude confirmar se os dados da quitação validam o valor apontado para esta embaixada (320 dobras) na lista de despesas com missões diplomáticas entre 1415 e 1473 publicada em Faro 1965, pp. 77-82.

${ }^{76}$ Esta média diz respeito a apenas 76 embaixadas, uma vez que não foi contabilizada uma em que o valor das despesas está expresso em libras. Este valor também deve ser olhado com reservas. Desde logo, porque houve algumas embaixadas que custaram muito mais do que a média, e outras muito menos. E também porque este número não tem em conta as variações no valor do dinheiro ao longo deste período. 
de 424 dobras, ou seja, cerca de $25 \%$ mais do que a que foi protagonizada pelo Prior do Carmo. Presume-se, portanto, que esta não terá sido uma embaixada particularmente cara.

\begin{tabular}{|l|c|}
\hline \multicolumn{1}{|c|}{ TIPO DE RECEITA } & VALOR (EM DUCADOS DE CÂMARA) \\
\hline Letra de câmbio (em Bruges) & 320 \\
\hline Depósito em Florença & 250 \\
\hline Letra de câmbio (em Roma) & 1.180 \\
\hline TOTAL & 1.750 \\
\hline
\end{tabular}

Quadro 1. Receitas da embaixada de D. João Manuel a Roma (1443-1445). Fonte: Azevedo 1915, p. 323.

Já se foi dando conta de como D. João Manuel foi obtendo liquidez para prosseguir a sua missão: num primeiro momento, em Bruges, descontou uma letra de câmbio no valor de 320 ducados de câmara; em Florença, após uma contenda com monges locais, obteve 250 ducados de um depósito lá realizado no tempo de D. Duarte; e em Roma descontou outra letra de câmbio, dessa vez no valor de 1.180 ducados. O total de receitas correspondeu a 1.750 ducados de câmara. As formas como este dinheiro foi parar às mãos do embaixador confirmam duas ideias sobre o financiamento da diplomacia portuguesa do século XV que já referi: por um lado, era habitual o recurso a letras de câmbio; por outro, o avultado depósito inaugurado por D. João I em Florença podia ter como um dos propósitos servir de suporte às operações diplomáticas desenvolvidas na Península Itálica ${ }^{77}$. Fica por esclarecer mais cabalmente o papel que a banca italiana desempenhava nestas missões, já assinalado por Virgínia $\mathrm{Rau}^{78}$.

As despesas totalizaram 2.226,5 ducados, 10 baiocas e 11 dobras. Optei por dividi-las em três categorias: a) os gastos relacionados com a missão propriamente dita (ou seja, o que se gastou para alcançar os objetivos da embaixada); b) os valores relativos às viagens; c) os custos com o pessoal (neste caso, um embaixador e três servidores). Na carta de quitação não há referências ao alojamento e à alimentação da comitiva ${ }^{79}$. Foi

${ }^{77}$ Não há qualquer sinal que permita deduzir que foi entregue ao embaixador uma soma em dinheiro antes da sua partida de Lisboa, tal como era hábito, por exemplo, na Saboia deste período. Pibiri 2011, p. 83.

${ }^{78}$ Rau 1986, p. 69.

${ }^{79}$ Ficam as dúvidas: teriam esses gastos de ser cobertos pelo dinheiro que cada um recebia por dia? Ou foram financiados de outra forma e por isso não constam nesta carta de quitação? 
o seguinte o peso de cada um destes grupos de despesas no custo total da embaixada:

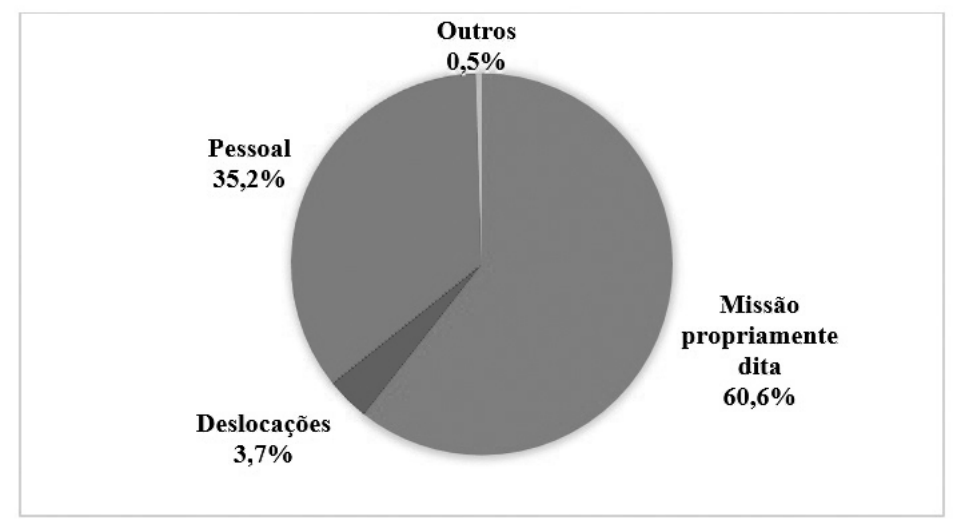

Gráfico 1. Peso relativo dos tipos de despesas da embaixada.

Fonte: Azevedo 1915, pp. 323-324.

Em linhas gerais, verifica-se que a maior parte do dinheiro $(61 \%)$ foi gasta no desenvolvimento de esforços junto da cúria romana para que fossem cumpridos os objetivos da missão. Em seguida, destacam-se os gastos com o pessoal, correspondentes a um terço das despesas desta embaixada. Os custos com as viagens, face ao total, revelam-se residuais. Seria esta distribuição do peso específico de cada tipo de despesas habitual? Face à ausência de elementos de comparação, não tenho como responder cabalmente. Mas é possível levantar algumas suposições:

- Acredito que fosse nas embaixadas enviadas ao papa que o peso dos gastos com a missão propriamente dita fosse mais elevado; em Roma não se negoceia com um igual; em Roma, na maior das vezes, só se pede, e o que se pede paga-se caro.

Certo é que esse valor, tendo em conta a duração da viagem, seria necessariamente significativo. $\mathrm{Na}$ embaixada navarra estudada por Iria Gonçalves, por exemplo, as despesas com alojamento e alimentação dos diplomatas e dos animais atingiram cerca de $95 \%$ dos gastos totais (tenha-se em conta, no entanto, que essa missão teve um perfil muito diferente da que aqui se trata: porque se realizou no século XIV, porque as viagens foram apenas terrestres e na Península Ibérica, porque o destinatário não era o papa e por isso não havia bulas para comprar, etc.). Gonçalves 1980 , p. 134. Fosse como fosse, longe iam os tempos em que os embaixadores da Roma antiga eram presenteados com um anel de ouro que lhe proporcionava acesso gratuito a transportes e alimentação em todos os territórios sob a jurisdição do Império... Queller 1967, p. 163. 
- O peso das despesas com pessoal devia variar muitíssimo em função do número de embaixadores, do perfil social dos diplomatas, da dimensão das suas comitivas, da duração e dos objetivos da missão; neste caso, estamos perante uma embaixada mais pequena do que talvez fosse habitual, constituída por um único embaixador (figura de prestígio, mas não de topo) e por três servidores, mas que também terá durado mais tempo do que a maioria das outras (cerca de um ano e meio).

- O reduzido peso das deslocações neste conjunto pode em parte ser explicado pela frequência com que diversas embarcações efetuavam os percursos que foram percorridos, o que poderia embaratecer o transporte.

Entre as despesas de cada uma das categorias definidas, há especificidades que importa assinalar.

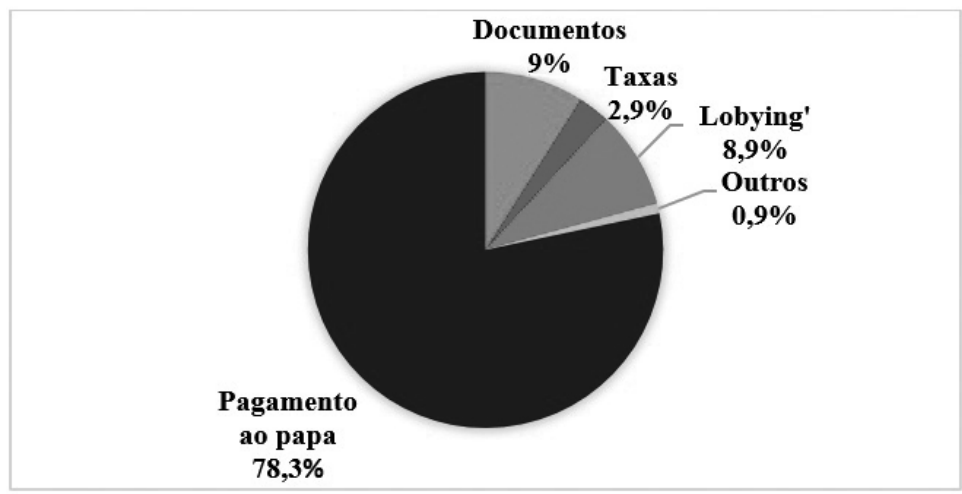

Gráfico 2. Despesas com a missão propriamente dita. Fonte: Azevedo 1915, p. 323.

No que toca às despesas com a missão propriamente dita, é esmagador o peso do pagamento ao papa, atingindo um valor perto dos $80 \%$. Seguem-se, com percentagens muito idênticas, os gastos com documentos e com o lobying. Apesar da importância das atividades de pressão e obtenção de influências nos corredores do Vaticano, acabava por se revelar muito mais pesado aquilo que era necessário pagar ao pontífice para se obter as decisões pretendidas. 


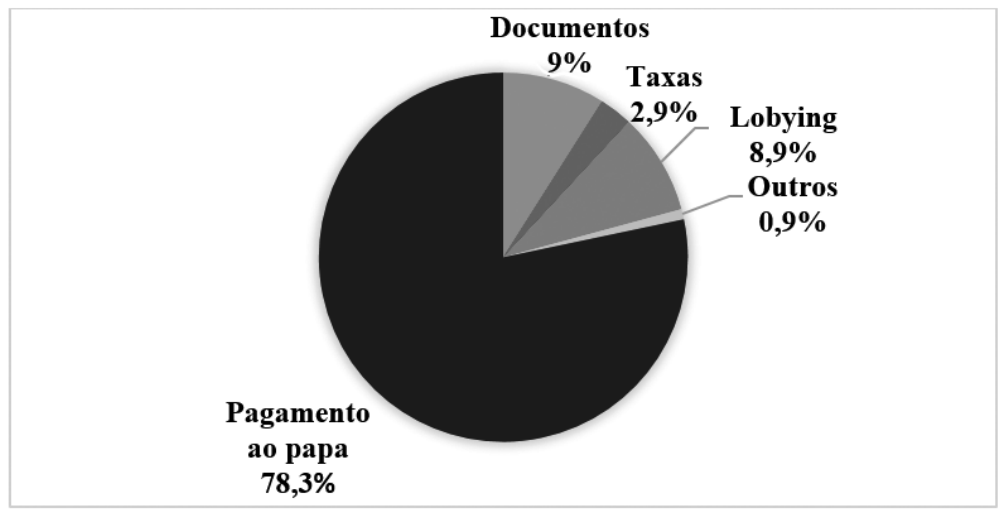

Gráfico 3. Despesas com viagens. Fonte: Azevedo 1915, pp. 323-324.

Em relação às viagens, verifica-se que ficou mais bastante mais cara a compra de quatro bestas, que terão sido utilizadas essencialmente no percurso entre Bruges e Roma, do que as viagens marítimas de Lisboa à Flandres e de Roma a Portugal. A já referida alta frequência de ligações entre estes espaços pode ajudar a compreender este fator.

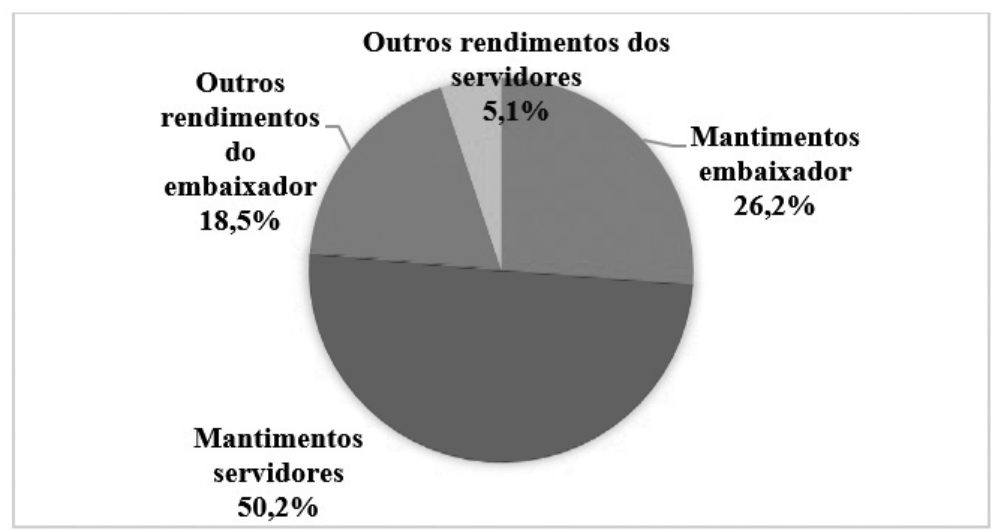

Gráfico 4. Despesas com pessoal. Fonte: Azevedo 1915, pp. 323-324.

Relativamente às despesas com pessoal, saliento três aspetos:

- Gastou-se sensivelmente menos nos pagamentos ao embaixador $(45 \%)$ do que à sua comitiva, constituída por mais três pessoas $(55 \%)$. 
- No que toca exclusivamente aos mantimentos, o embaixador recebia entre cerca de $70 \%$ a $150 \%$ mais do que os seus acompanhantes; durante o ano em que se encontraram em Roma, D. João Manuel recebeu meio ducado por dia, enquanto cada um dos seus servidores ganhou um terço de ducado por dia; já nos quatro meses e meio que durou o regresso a Portugal, o diplomata auferiu cinco ducados por mês, e os seus homens apenas dois.

- O valor (100 ducados) que o infante D. Pedro mandou dar de mercê a D. João Manuel não foi um prémio pelo seu bom desempenho durante esta missão; na verdade, tinha sido ordenado meses antes da partida da embaixada, através de um alvará assinado em Sintra em 17 de julho de 1443 .

- A forma como este embaixador foi pago está em linha com o que acontecia na generalidade das operações diplomáticas levadas a cabo pelas monarquias europeias deste tempo: foi-lhe atribuído um soldo diário, foi ressarcido pelas despesas em que incorreu durante este período, e não lhe foi feito qualquer pagamento antecipado ${ }^{80}$.

Para finalizar, note-se que esta embaixada foi financeiramente deficitária: um conjunto de ingressos de 1.750 ducados de câmara confrontou-se com despesas na ordem de 2.226,5 ducados, 10 baiocas e 11 dobras. Ou seja, houve um resultado negativo de 476,5 ducados, 10 baiocas e 11 dobras. Convertendo as dobras em ducados, na carta de quitação refere-se que o diplomata tinha a haver 517,5 ducados e 10 baiocas. As dificuldades de liquidez da coroa portuguesa não permitiram que fosse ressarcido imediatamente. Como era habitual, foram-lhe atribuídas receitas da fazenda régia: neste caso, as rendas da alfândega de Lisboa relativas ao ano de 1446.

\section{CONCLUSÃO}

A embaixada que D. João Manuel protagonizou entre 1443 e 1445 constitui hoje um caso singular no panorama da diplomacia portuguesa do século XV. À partida, quando se realizou, nada o faria supor: pelos seus objetivos e resultados (ou seja, pelo seu alcance político), não integra o grupo das mais significativas missões diplomáticas levadas a cabo neste período; para além disso, não se distinguiu pelo fausto, pela dimensão e composição da comitiva ou pela excentricidade de algum presente oferecido ao papa. Em

\footnotetext{
${ }^{80}$ Mattingly 1988, p. 31; Moeglin 2010.
} 
suma, teria tudo para ser apenas mais uma entre as dezenas de embaixadas enviadas pelos reis de Portugal à Santa Sé no final da Idade Média. Mas não foi apenas mais uma: nem para o homem que a protagonizou, nem para quem hoje procura estudar as relações externas portuguesas deste tempo.

Para D. João Manuel, esta ocasião foi, tanto quanto se sabe, a terceira e última vez que desempenhou funções de representação dos monarcas portugueses no estrangeiro. Partindo do reino como bispo de Tiberíades (um cargo honorífico) e prior da Ordem do Carmo, regressou como prelado de Ceuta, subindo um degrau importante na carreira eclesiástica que ainda o levaria a passar pela diocese da Guarda. Voltou de Roma, portanto, mais prestigiado e, provavelmente, mais rico. Durante o resto da sua vida, continuaria a ser uma personagem relevante na sociedade política portuguesa, tornando-se muito próximo do rei $\mathrm{D}$. Afonso $\mathrm{V}$.

Mas o que torna esta embaixada singular é o facto de ter dado origem a um documento -a carta de quitação de que me servi- que, por uma série de acasos, é provavelmente único no quadro das fontes portuguesas deste período. É verosímil que tenham sido emitidos muitos mais diplomas deste tipo: é natural que os embaixadores, no final das suas missões, tivessem de prestar contas do que gastaram; e não é menos lógico que essas contas dessem origem a cartas de quitação que seriam registadas nos livros da Chancelaria régia. Pelos mais diversos motivos (o terramoto de 1775, as invasões francesas, a destruição deliberada, a incúria...) uma grande parte desses volumes não chegou aos nossos dias. Mas chegou a quitação da missão de D. João Manuel a Roma. Graças a ela,é possível aproximarmo-nos de aspetos das relações externas medievais a que muito dificilmente acedemos com base noutros testemunhos: os itinerários, os transportes, o financiamento das missões, a dimensão das comitivas, os salários. As informações que contém, ainda que não colmatem a insuficiência documental sobre os aspetos práticos dos contactos internacionais da monarquia portuguesa deste período, podem constituir pontos de partida seguros para o desenvolvimento de novos inquéritos sobre o processo diplomático português do século XV.

10. APÊNDICE: DESPESAS DA EMBAIXADA

\begin{tabular}{|l|c|}
\hline \multicolumn{1}{|c|}{ TIPO DE DESPESA } & VALOR \\
\hline Missão propriamente dita & $1.350 \mathrm{~d} ., 10 \mathrm{~b}$. \\
\hline Viagens & $82 \mathrm{~d} ., 9 \mathrm{dob}$. \\
\hline Pessoal & $783.5 \mathrm{~d} ., 2 \mathrm{dob}$. \\
\hline Outros & $11 \mathrm{~d}$. \\
\hline TOTAL & $2.226,5 \mathrm{~d} ., 11 \mathrm{dob} ., 10 \mathrm{~b}$. \\
\hline
\end{tabular}

Quadro 2. Despesas por tipo de gasto. Fonte: Azevedo 1915, pp. 323-324. 


\begin{tabular}{|l|l|c|}
\hline \multicolumn{1}{|c|}{ TIPO DE DESPESA } & \multicolumn{1}{|c|}{ ITEM DE DESPESA } & VALOR \\
\hline Pagamento ao papa & Pagamento ao papa & $1.057 \mathrm{~d} ., 10 \mathrm{~b}$. \\
\hline Documentos & Bulas & $106 \mathrm{~d}$. \\
\cline { 2 - 3 } & $\begin{array}{l}\text { Letra de dispensa } \\
\text { matrimonial }\end{array}$ & $15 \mathrm{~d}$. \\
\hline \multirow{2}{*}{ 'Lobying' } & Pagamento a Mourensey & $100 \mathrm{~d}$. \\
\cline { 2 - 3 } & Pagamento ao taxador & $20 \mathrm{~d}$. \\
\hline Taxas & Taxas & $40 \mathrm{~d}$. \\
\hline Outros & $\begin{array}{l}\text { Secretário duque da } \\
\text { Borgonha }\end{array}$ & $2 \mathrm{~d}$. \\
\cline { 2 - 3 } & Porteiros do papa & $5 \mathrm{~d}$. \\
\cline { 2 - 3 } & Coisas miúdas & $1.350 \mathrm{~d} ., 10 \mathrm{~b}$. \\
\hline \multirow{2}{*}{ TotaL } & & \\
\hline
\end{tabular}

Quadro 3. Despesas com a missão propriamente dita. Fonte: Azevedo 1915, p. 323.

\begin{tabular}{|l|l|c|}
\hline \multicolumn{1}{c|}{ TIPO DE DESPESA } & \multicolumn{1}{|c|}{ ITEM DE DESPESA } & VALOR \\
\hline Bestas & Besta do embaixador & $20 \mathrm{~d}$. \\
\cline { 2 - 3 } & 3 bestas para servidores & $30 \mathrm{~d}$. \\
\hline Frete de embarcações & Carraca Lisboa - Bruges & $20 \mathrm{~d}$. \\
\cline { 2 - 3 } & Carraca Sagona - Cádiz & $12 \mathrm{~d}$. \\
& Barca Cádiz - Castro & 9 dob. \\
& Marim & $82 \mathrm{~d} ., 9$ dob. \\
\hline TotaL & &
\end{tabular}

Quadro 4. Despesas com viagens. Fonte: Azevedo 1915, pp. 323-324.

\begin{tabular}{|c|c|c|}
\hline TIPO DE DESPESA & ITEM DE DESPESA & VALOR \\
\hline \multirow[t]{3}{*}{ Mantimento do embaixador } & Estadia de 366 dias em Roma & $183 \mathrm{~d} .(0.5 \mathrm{~d} . / \mathrm{dia})$ \\
\hline & $\begin{array}{l}\text { Viagem de } 4,5 \text { meses de regresso } \\
\text { de Roma }\end{array}$ & 22,5 d. (5 d./mês) \\
\hline & $\begin{array}{l}\text { Viagem de Cádis a Castro } \\
\text { Marim }\end{array}$ & 2 dob. \\
\hline \multirow[t]{2}{*}{ Mantimento dos servidores } & Estadia de 366 dias em Roma & 366 d. (1/3 d. x 3/dia) \\
\hline & $\begin{array}{l}\text { Viagem de } 4,5 \text { meses de regresso } \\
\text { de Roma }\end{array}$ & 27 d. (2d./mês x 3) \\
\hline \multirow{2}{*}{$\begin{array}{l}\text { Outros rendimentos do } \\
\text { embaixador }\end{array}$} & Mercê & $100 \mathrm{~d}$. \\
\hline & Corregimento & $45 \mathrm{~d}$. \\
\hline $\begin{array}{lll}\text { Outros } & \text { rendimentos } & \text { dos } \\
\text { servidores } & & \end{array}$ & Vestiaria & $40 \mathrm{~d}$ \\
\hline \multicolumn{2}{|l|}{ TOTAL } & 783,5 d., 2 dob. \\
\hline
\end{tabular}

Quadro 5. Despesas com pessoal. Fonte: Azevedo 1915, pp. 323-324. 


\section{BIBLIOGRAFIA CITADA}

\section{FONTES IMPRESSAS}

Azevedo, Rui (ed.) (1915), Documentos das Chancelarias Reais anteriores a 1531 relativos a Marrocos, vol. I, Lisboa, Academia das Ciências de Lisboa.

Dias, Aida Fernanda (ed.) (2003), Diário da Jornada do Conde de Ourém ao Concílio de Basilea, Ourém, Câmara Municipal de Ourém.

Dinis, António Joaquim Dias (ed.) (1967), Monumenta Henricina, vol. VIII, Coimbra, Comissão Executiva das Comemorações do V Centenário da Morte do Infante D. Henrique.

Faro, Jorge (ed.) (1965), Receitas e Despesas da Fazenda Real de 1384 a 1481 (subsídios documentais), Lisboa, Publicações do Centro de Estudos Económicos.

Pina, Rui de (1977), Crónicas, Porto, Lello e Irmão.

\section{BIBLIOGRAFIA}

Almeida, Fortunato de (1967), História da Igreja em Portugal, vol. I, Porto, Portucalense Editora.

Baquero Moreno, Humberto (1973), A Batalha de Alfarrobeira. Antecedentes e significado histórico, Lourenço Marques, Universidade de Lourenço Marques (tese de doutoramento).

Beceiro Pita, Isabel (1997), La consolidación del personal diplomático entre Castilla y Portugal (1392-1455), em González Jiménez, Manuel (ed.), La Península Ibérica en la Era de los Descubrimientos. Actas III Jornadas Hispano-Portuguesas de Historia Medieval, Sevilha, Consejería de Cultura de la Junta de Andalucía, vol. II, pp. 1735-1744.

Beceiro Pita, Isabel (2009), Embajadas, viajes y relaciones culturales en el mundo ibérico (1370-1460), em Iglesia Duarte, José Ignasio de la (coord.), Viajar en la Edad Media. XIX Semana de Estudios Medievales, Nájera, del 4 al 8 de agosto de 2008, Logroño, Instituto de Estudios Riojanos, pp. 193-228.

Birch, Debra J. (2000), Pilgrimage to Rome in the Middle Ages, Woodbridge, The Boydell Press.

Black, Antony (1998), Popes and Councils, em Allmand, Christopher (dir.), The New Cambridge Medieval History, Cambridge, Cambridge University Press, vol. VII, pp. 65-86.

Braga, Isabel M.R. Mendes Drumond; Braga, Paulo Drumond (1998), Ceuta Portuguesa (1415-1656), Ceuta, Instituto de Estudios Ceutíes. 
Branco, Maria João; Farelo, Mário (2011), Diplomatic relations: Portugal and the others, em Mattoso, José (dir.), The Historiography of Medieval Portugal, c. 1950-2010, Lisboa, Instituto de Estudos Medievais, pp. 231-259.

Braudel, Fernand (1992), Civilização material, Economia e Capitalismo. Séculos XV-XVIII, vol. I, Lisboa, Teorema.

Coelho, Maria Helena da Cruz; Santos, Maria José Azevedo (1990), De Coimbra a Roma. Uma viagem em meados de Quinhentos, Coimbra, Coimbra Editora.

Coelho, Maria Helena da Cruz (2008), D. João I. O que re-colheu Boa Memória, Lisboa, Temas e Debates.

Costa, António Domingues de Sousa (1971), Carmelitas, em Serrão, Joel (dir.), Dicionário de História de Portugal, Porto, Livraria Figueirinhas, vol. I, p. 490.

Costa, João Paulo Oliveira e (2007), D. Manuel I. Um príncipe do Renascimento, Lisboa, Temas e Debates.

Duarte, Luís Miguel (2007), D. Duarte. Requiem por um rei triste, Lisboa, Temas e Debates.

Faria, Diogo (2013), A Chancelaria de D. Manuel I. Contribuição para o estudo da burocracia régia e os seus oficiais, Porto, Universidade do Porto (dissertação de mestrado).

Fletcher, Catherine (2015), Diplomacy in Renaissance Rome. The Rise of the Resident Ambassador, Cambridge, Cambridge University Press.

Fonseca, Luís Adão (1982), O Condestável D. Pedro de Portugal, Porto, Instituto Nacional de Investigação Científica.

Fragoso, José Manuel (1997), A História Diplomática de Portugal, Rio de Janeiro, Real Gabinete Português de Leitura.

Freire, Anselmo Braamcamp (1996), Brasões da Sala de Sintra, vol. III, Lisboa, Imprensa Nacional Casa da Moeda.

Freitas, Judite Antonieta Gonçalves de (1999), Teemos por bem e mandamos. A burocracia régia e os seus oficiais em meados de Quatrocentos (14391460), vol. I, Porto, Universidade do Porto (tese de doutoramento).

Gill, Joseph (1961), Eugenius IV, Pope of Christian Union, Londres, Burns $\&$ Oates.

Gonçalves, Iria (1971), Carta de quitação, em Serrão, Joel (dir.), Dicionário de História de Portugal, Porto, Livraria Figueirinhas, vol. III, p. 530.

Gonçalves, Iria (1980), Viajar na Idade Média: através da Península em meados do século XIV, "Arquipélago. Série de Ciências Sociais e Humanas" 2, pp. 119-142.

Hamilton, Keith; Langhorne, Richard (1995), The Practice of Diplomacy. Its evolution, theory and administration, Londres, Routledge. 
Homem, Armando Luís de Carvalho (1990), O Desembargo Régio (13201433), Porto, Instituto Nacional de Investigação Científica.

Lazzarini, Isabella (2010), La nomination d'un cardinal de famille entre l'Empire et la Papauté. Les pratiques de négociation de Bartolomeo Bonatti, orateur de Ludovico Gonzaga (Rome, 1461), em Andretta, Stefano; Péquignot, Stéphane; Schaub, Marie-Karine (eds.), Paroles de négociateurs. L'entretien dans la pratique diplomatique de la fin $d u$ Moyen Âge à la fin du XIX $X^{e}$ siècle, Roma, École Française de Rome, pp. 51-69.

Macedo, Jorge Borges de (2006), História Diplomática Portuguesa, constantes e linhas de força, Lisboa, Editorial Tribuna (primeira edição em 1987).

Magalhães, José Calvet de (2000), Breve História Diplomática de Portugal, Lisboa, Publicações Europa-América (primeira edição em 1990).

Marques, A. H. de Oliveira (1987), Portugal na crise dos séculos XIV e XV, Lisboa, Editorial Presença.

Marques, A. H. de Oliveira (1988), Guia do Estudante de História Medieval Portuguesa, Lisboa, Editorial Estampa (primeira edição de 1964).

Marques, José (2003-2004), Portugal e o Concílio de Basileia, "Revista Portuguesa de História” 36, pp. 71-88.

Marques, José (2015), A diocese de Ceuta na solicitude pastoral de D. Frei Justo Baldino (1478-1493), "Bracara Augusta" 60, pp. 5-33.

Martínez, Pedro Soares (2010), História Diplomática de Portugal, Coimbra, Almedina (primeira edição em 1985).

Mattingly, Gareth (1988), Renaissance Diplomacy, Nova Iorque, Dover Publications (primeira edição em 1955).

Miranda, Flávio (2012), Portugal and the Medieval Atlantic. Commercial Diplomacy, Merchants, and Trade, 1143-1488, Porto, Universidade do Porto (tese de doutoramento).

Moeglin, Jean-Marie (2010), La place des messagers et des ambassadeurs dans la diplomatie princière à la fin du Moyen Âge "Études de lettres" 3. Disponível em: http://edl.revues.org/249 [consulta: 15/10/2015].

Molina Molina, Ángel Luis (2000), Los viajes por mar en la Edad Media, "Cuadernos de Turismo" 5, pp. 113-122.

Manso, Visconde de Paiva (1872), História Ecclesiástica Ultramarina, vol. I, Lisboa, Imprensa Nacional.

Nunes, Eduar [Borges] (1964), Dom Frey Gomez, Abade de Florença. 14201440, Braga, Edição do autor.

Ochoa Brun, Miguel Ángel (1995), Historia de la Diplomacia Española, vol. III, Madrid, Ministerio de Asuntos Exteriores. 
Paviot, Jacques (1995), Portugal et Bourgogne au XV siècle, Lisboa, Centre Culturel Calouste Gulbenkian - Paris, Comission Nationale pour les Commémorations des Découvertes Portugaises.

Péquignot, Stéphane (2009), Au Nom du Roi. Pratique diplomatique et pouvoir durant le règne de Jacques II d'Aragon (1291-1327), Madrid, Casa de Velázquez.

Péquignot, Stéphane (2010), De bonnes et très gracieuses paroles. Les entretiens d'Antoni Vinyes, syndic de Barcelone, avec le roi d'Aragon Alphonse le Magnanime (Naples, 1451-1452), em Andretta, Stefano; Péquignot, Stéphane; Schaub, Marie-Karine (eds.), Paroles de négociateurs. L'entretien dans la pratique diplomatique de la fin du Moyen Âge à la fin du XIX ${ }^{e}$ siècle, Roma, École Française de Rome, pp. 27-50.

Péquignot, Stéphane (2011) Les diplomaties occidentales, XIII ${ }^{e}-X V^{e}$ siècle, em Les relations diplomatiques au moyen âge, formes et enjeux, Paris, Publications de la Sorbonne, pp. 47-66.

Péquignot, Stéphane (2012), Les diplomaties occidentales et le mouvement $d u$ monde, em Boucheron, Patrick (dir.), Histoire du monde au XV $V^{e}$ siècle, Paris, Pluriel, vol. II, pp. 536-561.

Pibiri, Eva (2011), En voyage pour Monseigneur. Ambassadeurs, officiers et messagers à la cour de Savoie (XIV ${ }^{e}-X V^{e}$ siècles), Lausanne, Société d'histoire de la Suisse Romande.

Plöger, Karsten (2005), England and the Avignon Popes. The Practice of Diplomacy in Late Medieval Europe, Londres, Modern Humanities Research Association and Maney Publishing.

Queller, Donald E. (1967), The Office of Ambassador in the Middle Ages, Princeton, Princeton University Press.

Rau, Virgínia (1986), Estudos de História Medieval, Lisboa, Editorial Presença.

Sá, Fr. Manuel de (1724), Memorias historicas dos ilustrissimos arcebispos, bispos e escritores portuguezes da Ordem de Nossa Senhora do Carmo, Lisboa, Oficina Ferreyriana.

Santarém, Manuel Francisco de Barros e Sousa, Visconde de $(1843,1866)$, Quadro Elementar das Relações Políticas e Diplomáticas de Portugal com as diversas potencias do mundo, desde o principio da monarchia portugueza até aos nossos dias, vols. III, X, Paris, J.P. Aillaud.

Serrão, Joaquim Veríssimo (2003), História de Portugal, vol. II, Lisboa, Editorial Verbo (primeira edição em 1977).

Shaw, Christine (2007), The Papal Court as a Center of Diplomacy from the Peace of Lodi to the Council of Trent, em Alazard, Florence; la Brasca, Frank (eds.), La Papauté à la Renaissance, Paris, Le Savoir de Mantice, pp. 621-638. 
Sousa, António Caetano de (1946), História Genealógica da Casa Real Portuguesa, vol. II, Coimbra, Atlântida.

Sousa, Armindo de (1997), 1325-1480, em Mattoso, José (coord.), A Monarquia Feudal (1096-1480), Lisboa, Editorial Estampa, pp. 263-466.

Spitzbarth, Anne-Brigitte (2013), Ambassades et ambassadeurs de Philippe le Bon, trosième duc Valois de Bourgogne (1419-1467), Turnhout, Brepols.

Uginet, François-Charles (1994), Eugène IV, em Levillain, Philippe (dir.), Dictionaire Historique de la Papauté, Paris, Fayard, pp. 642-645.

Ullman, Walter (2003), A Short History of the Papacy in the Middle Ages, Londres, Routledge (primeira edição em 1972).

Ventura, Margarida Garcez (2013), A Corte de D. Duarte. Política, cultura e afetos, Vila do Conde, Verso da História.

Watkins, John (2008), Toward a New Diplomatic History of Medieval and Early Modern Europe, "Journal of Medieval and Early Modern Studies" 38/1, pp. 1-14.

Fecha de recepción del artículo: diciembre 2015

Fecha de aceptación y versión final: enero 2017 